\title{
ГОМОМОРФІЗМ КОГНІТИВНИХ МОДЕЛЕЙ ПРЕДМЕТНОЇ ОБЛАСТІ ПРИ ПЕРЕДАЧІ ЗНАНЬ В ПІСЛЯДИПЛОМНІЙ МЕДИЧНІЙ ОСВІТІ
}

В. В. Краснов

\author{
Національна медична академія післядипломної освіти імені П. ^. Шупика
}

\begin{abstract}
Представлено поняття гомоморфізму когнітивних моделей предметної області. Запропоновано критерій гомоморфізму когнітивних моделей предметної області при передачі знань в системі післядипломної медичної освіти. Обґрунтовано рівні абстракції моделі предметної області.
\end{abstract}

Ключові слова: гомоморфізм, знання, рівні абстракції моделі.

\section{ГОМОМОРФИЗМ КОГНИТИВНЫХ МОДЕЛЕЙ ПРЕДМЕТНОЙ ОБЛАСТИ ПРИ ПЕРЕДАЧЕ ЗНАНИЙ В ПОСЛЕДИПЛОМНОМ МЕДИЦИНСКОМ ОБРАЗОВАНИИ}

\author{
Национальная медицинская академия последипиомного образования имени П. Шупика
}

Представлено понятие гомоморфизма когнитивных моделей предметной области. Предложен критерий гомоморфизма когнитивных моделей предметной области при передаче знаний в системе последипломного медицинского образования. Обоснованы уровни абстракции модели предметной области.

Ключевые слова: гомоморфизм, знания, уровни абстракции модели.

\section{HOMOMORPHISM OF COGNITIVE SUBJECT DOMAIN MODEL BY KNOWLEDGE TRANSFER IN POST-GRADUATE MEDICAL EDUCATION}

V. V. Krasnov

\author{
National Medical Academy of Post-Graduate Education by P. L. Shupyk
}

There is presented the notion of homomorphism cognitive domain subject models. The homomorphism criterion of cognitive models in domain knowledge transfer in the system of post-graduate medical education is offered. Reasonable level of abstraction of the domain subject model is substatiated.

Key words: homomorphism, knowledge, levels of model abstraction.

Вступ. Одне з основних завдань системи освіти полягає в забезпеченні точності передачі знань. Вважається, що навколишня дійсність при сприйнятті ії людиною відображається в мозку у вигляді когнітивних образів. 3 деякою умовністю можна сказати, що когнітивні образи є моделями навколишньої дійсності [1].

При передачі знань, зазвичай, говорять про отримання двох образів (моделей) однієї і тієї ж дійсності: перша $\left(M_{g}\right)$ - в пам'яті експерта і друга $\left(P_{z q}^{i j}\right)$ - в пам яті того, кого навчають. Причому обидві ці моделі не є однаковими [2].

Додатковим компонентом, який вносить суттєві викривлення в ці моделі, є заміна вербального контакту на текстологічний. У цьому випадку експерт і учень не спілкуються, а учень читає повідомлення, що передаються експертом. Серед методів отримання знань цей напрямок вважається найменш розробленим. В текстологічній передачі знань можна виділити дві такі смислові структури: $M_{l}$ - смисл, який намагався закласти автор (це його модель світу), i $M_{2}$ - смисл, який осягає читач в процесі інтерпретації $I$. При цьому $T$ - це словесне уявлення $M$ тобто результат вербалізації $V$. Вважають, що складність процесу передачі знань полягає у принциповій неможливості збігу знань, які створюють $M_{l}$ і $M_{2}$ через те, що $M_{l}$ утворюється за рахунок всієї сукупності уявлень, потреб, інтересів та досвіду автора, лише мала частина яких знаходить відображення в тексті $T$.

(C) В. В. Краснов 
Відповідно, і $M_{2}$ утворюється в процесі інтерпретації тексту $T$ за рахунок залучення всієї сукупності наукового і людського багажу читача. В результаті два фахівці витягнуть з одного тексту $T$ дві різні моделі $M_{1}^{I}$ і $M_{2}^{l}$ Отже, під розумінням тексту можна вважати процес відтворення семантичної структури $M_{1}$ в процесі формування моделі $M_{2}$

Для сучасних систем освіти актуальним є завдання забезпечення максимальної відповідності двох образів деякої предметної області (ПО). Вважається, що дві системи називаються ізоморфними, якщо між їх елементами, а також функціями (операціями), властивостями і відносинами, осмисленими для цих систем, існує або може бути встановлено взаємооднозначну відповідність. У цьому випадку кожна із систем називається ізоморфним образом іншої. Згідно з визначенням, ізоморфізм і гомоморфізм - це поняття, що виражають однаковість (ізоморфізм; від грец. Isos - однаковий і morphe - форма) або подібність (гомоморфізм; від грец. Homoios - подібний) будови (структури) систем (множин, процесів, конструкцій) [3].

Класично, концептуальний аналіз ПО грунтується на структурному аналізі та побудові ієрархічноїмережі понять («піраміда знань»). Під "пірамідою знань" розуміють ієрархічну послідовність понять, рух по якій означає поглиблення розуміння і підвищення рівня абстракції (узагальненості) понять. Кількість рівнів у піраміді залежить від особливостей ПО, професіоналізму експертів та слухачів [2]. Чим вище в ієрархії знань перебуває модель, тим більшою абсmрактністю вона володіє [1]. Під абстракцією (від лат. Abstractio - «відволікання») розуміють відволікання в процесі пізнання від несуттєвих сторін, властивостей, зв'язків предмета чи явища з метою виділення їх істотних, закономірних ознак [4].

Мета. Розробити системи структурування процедурних знань для забезпечення максимального гомоморфізму когнітивних моделей ПО в експерта i того, хто навчається.

Матеріали та методи. В дослідженнях брали участь дві групи слухачів (лікарі-інтерни за фахом акушерство-гінекологія $(\mathrm{n}=128))$, які навчалися в чотирьох медичних вищих навчальних закладах України. Кожна з груп працювала з формалізованими моделями ПО різних рівнів абстракції. Методи дослідження: експертні оцінки, перевірка рівня знань за допомогою альтернативних тестів, тестів відкритого типу, та тестів на визначення послідовності відповіді.

Основна частина. За аналогією 3 принципами трансляції знань [2] було прийнято, що при описі про- цесів передачі знань можна виділити шість основних моделей відображення ПО (рис. 1):

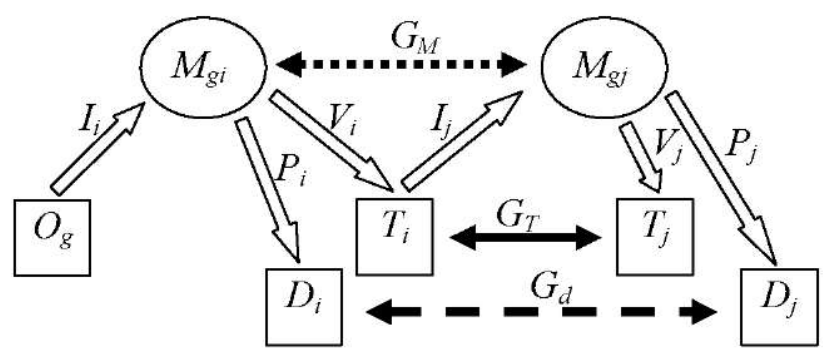

Puc. 1. Схематичне відображення структурних елементів процесу трансляції знань за допомогою текстологічних методів.

1. Когнітивна модель ПО $M$., яку будує експерт $\&$. в процесі сприйняття та інтерпретації $I$ дійсності $O$

2. Формалізована знакова (текстова) модель $T$, яку будує експерт у процесі вербалізації V знань.

3. Когнітивна модель ПО M., яку будує учень в процесі сприйняття та інтерпретації I текстової моделі $T$.

4. Модель, що відображає результати фізичного здійснення дій $Б$ які виробляє експерт на підставі практичної реалізації $P$ індивідуальної когнітивної моделі ПО.

5. Формалізована знакова (текстова) модель $T$ яку будує той, кого навчають, в процесі вербалізації $V$. знань.

6. Модель, що відображає результати фізичного здійснення дій $Б$, які виробляє той, кого навчають, на підставі практичної реалізації $P$. індивідуальної когнітивної моделі ПО.

На основі когнітивної моделі ПО фахівець виробляє дії та/або описує їх. Тому, якщо говорити про передачу знань від експерта до того, кого навчають, то про результативність цього процесу свідчить точність відпо-

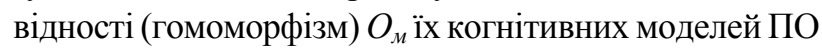
$M$ і $M$ Але для опису форми когнітивного простору не існує прямих методів. Про точність побудованої картини світу судять за зовнішніми проявами, які на ній базуються. Подібні прояви можна умовно поділити на дві групи: дії $Б$ і вербалізація $T$. Системи освіти вже сотні років використовують принципи текстологічного відображення досвіду експерта. Це дозволяє тиражувати унікальні знання. При роботі з підручниками учні сприймають знання, що дає можливість викладачеві забезпечити масовість освіти, а також при формуванні умінь працювати вже не з "чистого аркуша", а спиратися на фундамент знань, отриманих при читанні. Таким чином, чим точніше побудована формалізована знакова (текстова) модель $T_{i}$ яку будує експерт у процесі вербалізації $V_{i}$ своєї когнітивної моделіПО $M_{g i}$, тим точніше той, хто навчається, зможе побудувати вже свою 
когнітивну модель ПО $M_{\text {g. }}$ Про точність відповідності когнітивних моделей експерта та учня можна судити за ступенем гомоморфізму $G_{T}$ їх формалізованих знакових (текстових) моделей $\left(T_{i}\right.$ i $T_{j}$ відповідно).
Для визначення гомоморфізму було визначено принципи структуризації ПО. В результаті роботи експертів було запропоновано 5 рівнів абстракції когнітивної моделі ПО (табл. 1).

Таблиця 1. Рівні абстракції системи, яка описує ПО

\begin{tabular}{|c|c|}
\hline $\begin{array}{l}\text { Рівні } \\
\text { абстракції } \\
\text { моделі }\end{array}$ & Складові рівня абстракції \\
\hline $\mathrm{V}$ & Об'єкти і властивості об'єктів (функціональне призначення) \\
\hline IV & Відносини між об'єктами \\
\hline III & $\begin{array}{l}\text { Відносини в парі: "ситуація - об'єкт". Т.ч. або ситуація або об'єкт можуть бути } \\
\text { системоутворювальним чинником для структурних концептів знань. При цьому ситуація } \\
\text { може розглядатися як фактор, який актуалізує або редукує ситуаційні властивості об'єктів }\end{array}$ \\
\hline IIIa & Взаємооднозначна відповідність в парах "ситуація - об'єкт" \\
\hline Шб & Багатозначна прямо спрямована відповідність "об'єкт - набір ситуацій" \\
\hline Шв & $\begin{array}{l}\text { Багатозначна зворотно спрямована відповідність "ситуація - набір об'єктів, які } \\
\text { супроводжують дану ситуацію". }\end{array}$ \\
\hline Шг & $\begin{array}{l}\text { Функціональне обмеження. У випадках, коли подія (ситуація) та/або мета, виділяють } 3 \\
\text { безлічі функціональних можливостей структурної компоненти саме ті, які мають відношення } \\
\text { до даної ситуації }\end{array}$ \\
\hline II & $\begin{array}{l}\text { Системний. У випадках, коли подія (ситуація) та/або мета щодо вирішення цієї ситуації } \\
\text { структурує всі компоненти і зв'язки між ними для досягнення мети }\end{array}$ \\
\hline I & $\begin{array}{l}\text { Стандартизована система верхнього рівня, яка описує набори спадкоємних ситуацій } \\
\text { (процесу, який змінюється в часі) і задає спадкоємну послідовність об'єктів і дій з ними. } \\
\text { Реалізується ланцюжок: подія (як набір відхилених параметрів) - мета (як набір } \\
\text { нормалізованих параметрів) - вплив (як набір динамічно змінних параметрів) і знову подія } \\
\text { (як набір змінених параметрів). }\end{array}$ \\
\hline
\end{tabular}

Для кожного рівня абстракції визначалися критерії гомоморфізму і ступінь гомоморфізму при передачі знань від експерта до слухача.

Для визначення точності сприйняття формалізованої моделі ПО, побудованої експертами, використовувалися тестові та експертні методики. Вважалося, що гомоморфізм формалізованої моделі ПО, побудованої експертами, та когнітивної моделі ПО того, хто навчається, дорівнює 100 \% у тому випадку, якщо результати перевірок знань збігаються 3 еталоном. Ступінь збігу визначався за процентною шкалою.

На периому кроцуі побудови інтегральної оцінки, яка свідчить про ступінь гомоморфізму формалізованих когнітивних моделей ПО, оцінювався рівень засвоєння знань для кожного рівня абстракції окремо. Числовий вираз ступеня гомоморфізму $g$ визна-

чався як $g^{k}=\frac{\sum_{i=1}^{n} x_{i}^{k}}{n}$, де х - оцінка, отримана в результаті виконання 7 - го завдання; $\kappa$ - рівень абстракції моделі, $n$ - кількість перевірок на збіг з еталоном. В результаті контрольних процедур для кожно- го учня і для кожного рівня абстракції моделі були отримані відповідні оцінки.

На другому кроці визначалася власне сама інтегральна оцінка, яка відображала ступінь засвоєння знань на всіх рівнях абстракції. Числовий вираз ступеня гомоморфізму для загальної моделі $\mathrm{O}^{7}$ визначався як тангенс кута нахилу лінійної регресії, що описує характер розподілу середніх арифметичних за ступенями засвоєння знань на кожному рівні абстракції $g^{k}$. Або $G^{i}=\operatorname{tg} \beta=\frac{1}{a}$ де $a$ є коефіцієнтом регресійного рівняння виду: $y=a x+b$. При цьому критерій гомоморфізму $O$ змінюється в діапазоні від 0 до $100 \%$. Отримана в результаті розрахунків оцінка свідчить про ступінь збігу когнітивної моделі ПО учня з формалізованою моделлю ПО, яку побудували експерти.

В результаті проведених досліджень визначено, що у слухачів, які працювали зі структурованими текстами (електронні навчальні посібники процедурного типу), ступінь гомоморфізму на 30 \% перевищував ступінь гомоморфізму в іншій групі, яка працювала із традиційними навчальними матеріалами. Ці висновки були підтверджені експертними оцінками. 
Висновок. Результативність системи післядипломної медичної освіти $є$ тим вищою, чим вищим $€$ гомоморфізм моделей дій того, хто навчає, і того, хто навчається. Пошук підходів з визначення гомоморфізму та його підвищення є одним з головних зав-

\section{Лiтература}

1. Turchin V On Cybernetic Epistemology. Systems Research. Vol.10.- No.1, 1993.- p. 3-28.

2. Гаврилова Т. А. Базы знаний интеллектуальных систем / Т. А. Гаврилова, В. Ф. Хорошевский. - СПб. : Питер, 2000. $384 \mathrm{c}$.

3. Анфилатов В. С. Системный анализ в управлении : учеб- дань освіти. В свою чергу, поділ предметної області на різні рівні абстракції і використання для кожного рівня системи контролю цих знань, які засновані на ̈х структурованості, дає можливість визначити точність передачі знань у системі викладач-слухач.

ное пособие / В. С. Анфилатов, А. А. Емельянов, А. А. Кукушкин / Под ред. А. А. Емельянова. - М. : Финансы и статистика. - 2002. - 368 с.

4. Философия науки : учебное пособие для вузов / Под ред. С. А. Лебедева. Изд. 5-е, перераб. и доп. - М. : Академический Проект; Альма Матер. - 2007. - 731 с. 